\title{
Peculiarities of thermal aggregation of bovine serum albumin in the presence of strong polyelectrolytes
}

\author{
(C) Natalia N. Smirnova, ${ }^{1 *+}$ and Kirill V. Smirnov ${ }^{2}$ \\ ${ }^{1}$ Department of chemistry. Vladimir State University named after A.G. and N.G. Stoletovs. \\ Gorkogo St., 87. Vladimir, 600000. Russia.Phone: +7 (9422) 47-97-41.E-mail: smirnovann@list.ru \\ ${ }^{2}$ Department of biology and ecology. Vladimir State University named after A.G. and N.G. Stoletovs. \\ Gorkogo St., 87. Vladimir, 600000.Russia.Phone: +7 (9422) 47-97-41.E-mail: kirillv.smirnov@yandex.ru
}

*Supervising author; ${ }^{+}$Corresponding author Keywords: bovine serum albumin, polyelectrolytes, interpolyelectrolyte reactions, protein-polyelectrolyte complexes.

\begin{abstract}
The influence of temperature on bovine serum albumin (BSA) aggregation in aqueous solutions in the presence of poly- $N, N$-dimethyl- $N, N$-diallylammonium chloride (PDMDAAC) and the sodium salt of carboxymethylcellulose (CMC) was studied. It was shown that protein-polyelectrolyte complexes (PPC) form because of macromolecular reactions that are stabilized mainly by electrostatic forces. To characterize the PPC composition the $\varphi$ parameter was used. This parameter is defined as the ratio of the concentration of ionic groups of polyelectrolyte per protein molecules. It was studied that when in an interpolyelectrolyte reaction, a sufficiently high degree of transformation occurs the polymer electrolyte initiates aggregation of protein molecules. As the temperature increases, the initiating role of the polymer electrolyte increases due to an increase in the intensity of hydrophobic interactions. Using the method of spectrophotometry, it was found that, depending on the nature of the polymer electrolyte, insoluble complexes of bovine serum albumin are formed when the $\mathrm{pH}$ parameter is above or below the isoelectric point of the protein, when its macromolecules are negatively or positively charged. In the presence of poly- $N, N$-dimethyl- $N, N$-diallylammonium chloride, the intensive formation of aggregates and their rapid precipitation in the form of flakes at $\mathrm{pH}>7.0$ was observed when the temperature increased to $60{ }^{\circ} \mathrm{C}$. The maximum yield of the product of the interpolyelectrolyte reaction bovine serum albumin - sodium salt of carboxymethylcellulose was detected at $\mathrm{pH} \leq 4.0$. A temperature increase up to $60{ }^{\circ} \mathrm{C}$, in this case, was not accompanied by intensive flocculation. Under optimal composition and interaction conditions, the degree of transformation in the BSA - PDMDAAX and BSA - CMC reactions is $\sim 0.93$ and 0.9 , respectively, and decreases by $\sim 5-7 \%$ with an increase in temperature to $60{ }^{\circ} \mathrm{C}$. It was shown that for the same BOD composition (the ratio of components in the $[\mathrm{CMC}] /[\mathrm{BSA}]$ complex $=0.1 \mathrm{~g} / \mathrm{g}$ ), an increase in temperature from 25 to $60{ }^{\circ} \mathrm{C}$ leads to the formation of particles that increase in size from $1 \mathrm{mcm}$ to $5 \mathrm{mcm}$. The temperature increase leads to a change in composition of BOD, corresponding to its maximum output as a interpolyelectrolyte reactions product: for complex with PDMDAAC at $\mathrm{T}=25,40$ and $60^{\circ} \mathrm{C}$, the $\varphi$ value is $70,60,15$; for the complex with the $\mathrm{CMC}-$ $60,50,20$.
\end{abstract}

\section{References}

[1] Macromolecular protein complexes. Structure and function. Ed. by J. Robin Harris, J. Marles-Wright. Switzerland: Springer. 2017. 572p.

[2] V.A. Kabanov. Polyelectrolyte complexes in solution and in condensed phase. Russ. Chem. Rev. 2005. Vol.74. No.1. P.5-24. (russian)

[3] Polyelectrolytes. Ed. by P.M. Visakh, O. Bayraktar, G.A. Picó. Switzerland: Springer. 2014. 388p.

[4] Polyelectrolyte complexes in the dispersed and solid state. I Principles and theory. Ed. by M. Müller. Berlin, Heidelberg: Springer. 2014. 229p.

[5] V.A. Izumrudov. Phenomenon of self-Assembly and molecular "recognition" in solutions of (bio)polyelectrolyte complexes. Russ. Chem. Rev. 2008. Vol.77. No.4. P.401-414. (russian)

[6] Polyelectrolyte complexes in the dispersed and solid state. II Application aspects. Ed. by M. Müller. Berlin, Heidelberg: Springer. 2014. 264p.

[7] C.L. Cooper, P.L. Dubin, A.B. Kayitmazer, S. Turksen. Polyelectrolyte-protein complexes. Current Opinion Coll. Int. Sci. 2005. Vol.10. P.52-78. 
[8] Macromolecular complexes in chemistry and biology. Ed. by P. Dubin, J. Bock, R. Davis, D.N. Schulz, C. Thies. Berlin, Heidelberg: Springer-Verlag. 1994. 360p.

[9] J. Lombardi, V. Woitovich, G. Picó, V. Boeris. Obtainment of a highly concentrated pancreatic serine proteases extract from bovine pancreas by precipitation with polyacrylate. Sep. Purif. Technol. 2013. Vol.116. P.170-178.

[10] T. Kurinomaru, T. Maruyama, S. Izaki, K. Handa, T. Kimoto, K. Shiraki. Protein-poly(amino acid)complex precipitation for high-concentration protein formulation. J. Pharmaceut. Sci. 2014. Vol.103. P.2248-2254.

[11] I.N. Shalova, R.A. Asryants, M.V. Sholukh, L. Saso, B.I. Kurganov, V.I. Muronetz, V.A. Izumrudov. Interaction of polyanions with basic proteins: influence of complexing polyanions on the thermoaggregation of oligomeric enzymes. Macromol Biosci. 2005. Vol.5. P.1184-1192.

[12] O.N. Ivinova, V.A. Izumrudov, V.I. Muronetz, I.Y. Galaev, B. Mattiasson. Influence of complexing polyanions on the thermostability of basic proteins. Macromol Biosci. 2003. Vol.3. P.210-215.

[13] I.N. Shalova, I.N. Naletova, L. Saso, V.I. Muronetz, V.A. Izumrudov. Interaction of polyelectrolytes with proteins: influence of complexing polycations on the thermoaggregation of oligomeric enzymes. Macromol Biosci. 2007. Vol.7. P.929-939.

[14] A.N. Cherkasov. Rapid analysis of ultrafiltration. Membr. Struct. Separ. Sci. and Technol. 2005. Vol.40. No.14. P.2775-2801.

[15] D.C. Carter, J.X. Ho. Structure of serum albumin. Adv Protein Chem. 1994. Vol.45. P.153-203.

[16] M. Kodaka. Requirements for generating sigmoidal time-course aggregation in nucleation-dependent polymerization model. Biophys Chem. 2004. Vol.107. P.243-253.

[17] M.A. Speed, J. King, D.I.C. Wang. Polymerization mechanism of polypeptide chain aggregation. Biotechnol Bioeng. 1997. Vol.54. P.333-343.

[18] A. Tobitani, S.B. Ross-Murphy. Heat-induced gelation of globular proteins: effect of environmental factors on single-component and mixedprotein gels. Macromolecules. 1997. Vol.30. P.4855-4862.

[19] V. Vetri, M. D'Amico, V. Fodera, M. Leone, A. Ponzoni, G. Sberveglieri, V. Militello. Bovine serum albumin protofibril-like aggregates formation: solo but not simple mechanism. Arch. Biochem.Biophys. 2011. Vol.508. P.13-24.

[20] G. Shanmugam, P. Polavarapu. Vibrational circular dichroism spectra of protein films: thermal denaturetion of bovine serum albumin. Biophys. Chem. 2004. Vol.111. P.73-77.

[21] S. Ferraris, M. Cazzolo, V. Peretti, B. Stella, S. Spriano. Zeta Potential Measurements on Solid Surfaces for in Vitro Biomaterials Testing: Surface Charge, Reactivity Upon Contact With Fluids and Protein Absorption. Front. Bioeng. Biotechnol. 2018. https://doi.org/10.3389/fbioe. 2018.00060

[22] F. Vasheghani, F.H. Rrajabi, M.H. Ahmadi, S. Nouhi. Stability and thermodynamic parameters of some selective intermacromolecular complexation. Polymer Bulletin. 2006. Vol.56. P.395-404.

[23] N.N. Smirnova, A.Yu. Kulagina, Yu.A. Fedotov. Influence of temperature on complexation of sulfonate-containing polyphenylenephthalamides and poly- $N$-(2-aminoethyl)acrylamide in aqueous solution. Izv. Vyssh. Uchebn. Zaved. Khim. Khim. Tekhnol. 2011. Vol.54. Iss.3. P.32-36. (russian)

[24] N.N. Smirnova, E.S. Ilina, and K.V. Smirnov. Protein-polyelectrolyte complexes. Part 1. Complexes bovine serum albumin with carboxymethylcellulose. Influence factor the flocculation of protein. Butlerov Communications. 2018. Vol.54. No.6. P.144-148. DOI: 10.37952/ROI-jbc-01/18-54-6-144

[25] N.N. Smirnova, E.S. Ilina, and K.V. Smirnov. Protein-polyelectrolyte complexes. Part 2. Complexes bovine serum albumin with carboxymethylcellulose. Effect of molecular weight of polyelectrolyte. Butlerov Communications. 2018. Vol.55. No.7. P.142-147. DOI: 10.37952/ROI-jbc-01/18-54-7-142

[26] L. Ahmed, J. Xia, P. Dubin, E. Kokufuta. Stoichiometry and mechanism of complex formation proteinpolyelectrolyte coacervation. J. Macromol. Sci. Part A: Pure Appl. Chem. 1994. Vol.31. No.1. P.17-29.

[27] V.B. Skobeleva, A.V. Zinchenko, V.B. Rogacheva, A.B. Zezin. Interaction of weak polyamine with bovine serum albumin. Vestn. Mosk. Univ. Ser. 2. Chemistry. 1998. Vol.39. No.4. P.268-271. (russian) 